\title{
基本操作手技習熟度の定量評価とチェックシートを用いた シナリオ達成度評価の関係性の検討
}

\author{
小松真也 ${ }^{1)} \cdot$ 二宮伸治 ${ }^{2)}$
}

\begin{abstract}
要旨
体外循環操作訓練の評価は指導者に委ねられているが、多人数を対象とする場合は、訓練者自ら評価を行える環 境が望ましい。この環境を構築して総合的な能力の評価を実施するには、シナリオトレーニングを定量的に評価で きる手法を確立し、基本操作手技とシナリオトレーニングの定量評価の関倸性を明らかにする必要がある。

本研究では養成校に㧍ける学生 91 名を対象とし、シナリオトレーニングにチェックシート手法を導入して達成度 の定量評価を行う環境を構築した。次に基本操作手技およびシナリオ達成度評価の関係性を検討するため、血圧維 持を課題とする基本操作手技評価の後にシナリオトレーニング評価した群と、逆の順序で実施した群に分類し、そ れぞれの評価を比較した。

その結果、基本操作手技評価を先に実施した群は、シナリオトレーニング時に有意に血圧維持習熟度が上昇した が、シナリオ達成度評価には有意差が認められなかった。このことより体外循環操作の総合的な能力を評価するた めには、基本操作手技とシナリオ達成度の定量評価を統合したトレーニング様式を検討する必要が示唆された。
\end{abstract}

索引用語：体外循環操作、シナリオトレーニング、多人数教育、評価手法、体外循環シミュレー夕

Study on relationship between quantitative evaluation of the basic operation technique skill level and scenario achievement evaluation using a check sheet

Shinya Komatsu ${ }^{1)}$, Shinji Ninomiya ${ }^{2)}$

Abstract : Although evaluation of extracorporeal circulation operation training is entrusted to leaders, environment is desirable to evaluate themselves by trainee when the target is a many people. At first establish a method capable of quantitatively evaluating the scenario training in order to build the environment, further it is necessary to clarify the relationship between the quantitative evaluation of the basic operation technique and scenario training in order to evaluate the overall competence.

Targets in this study as 91 students of the training school, it was constructed environment to perform a quantitative evaluation of achievement by introducing a check sheet method to scenario training. Next, in order to examine the relationship between evaluation of the basic operation technique and scenario achievement, we compared the each of evaluation by classifying the groups to evaluate scenario training after the evaluation of the basic operation technique that is an object of the blood pressure maintenance and to evaluate in the reverse order.

As a result, significant difference was not observed to the scenario achievement evaluation in the group was carried out before the evaluation of the basic operation technique, although blood pressure maintain skill level has increased significantly when scenario training. From this thing, it has been suggested need to consider the training style that integrates quantitative evaluation of basic operation technique and scenarios achievement in order to evaluate the overall competence of extracorporeal circulation operation.

Key words : extracorporeal circulation operation, scenario training, many people education, evaluation method, extracorporeal circulation simulator (ECCSIM)

1）広島国際大学大学院 医療・福祉科学研究科 医療工学専攻 小松真也 (Shinya Komatsu)

干 739-2695 広島県東広島市黒瀬学園台 555-36

Major in Medical Engineering and Technology, Graduate School of Medical Technology and Health Welfare Sciences, Hiroshima International University

555-36, Kurosegakuendai, Higashihiroshima, Hiroshima, 739-2695, Japan

2) 広島国際大学 保健医療学部 医療技術学科

[原稿受領日 : 2015 年 9 月 30 日 採択日：2015 年 11 月 16 日] 


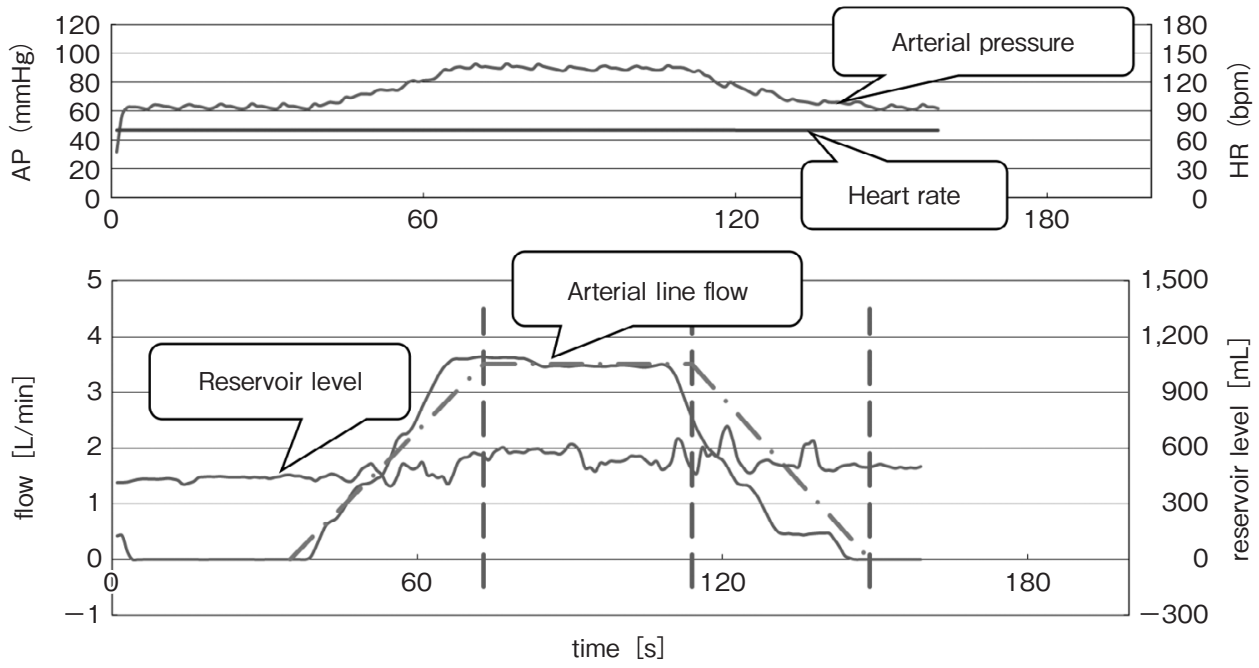

The gap and standard deviation to a desired value

\begin{tabular}{ccccc}
\hline & $\begin{array}{c}\text { Change of reservoir level } \\
{[\mathrm{mL}]}\end{array}$ & $\begin{array}{c}\text { Change of arterial flow } \\
{[\mathrm{L} / \mathrm{min}]}\end{array}$ & $\begin{array}{c}\text { Change of drain flow } \\
{[\mathrm{L} / \mathrm{min}]}\end{array}$ & $\begin{array}{c}\text { Change of arterial pressure } \\
{[\mathrm{mmHg}]}\end{array}$ \\
\hline $\mathrm{I}$ & $-37.1 \pm 38.6$ & $0.86 \pm 0.61$ & $0.64 \pm 0.65$ & $-3.54 \pm 8.61$ \\
$\mathrm{II}$ & $52.8 \pm 38.2$ & $0.40 \pm 0.44$ & $0.20 \pm 0.72$ & $9.65 \pm 1.12$ \\
$\mathrm{II}$ & $34.2 \pm 63.4$ & $-2.38 \pm 0.30$ & $-2.46 \pm 0.65$ & $-11.76 \pm 4.93$ \\
\hline & & & Whole average $=$ & $-0.38 \pm 10.41$ \\
\cline { 5 - 5 } & & &
\end{tabular}

図 1 トレンドグラフおよび各数値の変動における平均值と標準偏差

(図中の番号 :「I , Extra corporeal circulation start $\rightarrow$ Total flow」「II, Total flow $\rightarrow$ Weaning start $\rfloor$

$\ulcorner$ III, Weaning start $\rightarrow$ Extra corporeal circulation stop $\rfloor)$

\section{I . 緒言}

臨床における体外循環操作では、基本操作手技だけ でなく「認知と判断を実行に移す能力」や「コミュニ ケーション能力」など、各能力を同時に実施する総合 的な能力が要求される。日本人工臟器学会が開催する ウエットラボに参加した報告 ${ }^{1-3)}$ では、指導教官と受 講者、両方の立場から定期的にトレーニングを行うこ との重要性が述べられている。また、日本体外循環技 術医学会が行ったアンケート（2014）の結果報告 4) で は、人工心肺トラブルシミュレーションを行っている 施設が $83.1 \%$ (450 施設中 374 施設)であると報告され、 臨床現場においてトレーニングの重要性が認識されて いる。様々なトレーニングが存在する中で、体外循環 操作で要求される総合的な能力を効率よく育成するた めには、状況認識に関する気づきを導き出せるシミュ レーショントレーニング手法の導入が有効であると考 える。

著者らは、トレーニング時の各数值を記録しトレンド グラフ（図 1）を表示する機能がある体外循環シミュレ 一夕 ECCSIM (ExtraCorporeal Circulation SIMulator) の開発を継続してきた ${ }^{5-8)}$ 。更に養成校教育にシミュレ ーショントレーニング手法を導入するために、学生自 ら本システムを用いて、基本操作手技に関して定量評 価できる環境を構築した。
しかし、養成校教育では多人数を対象とするため、指 導者の存在に依存することなく、訓練者相互で評価を 行える環境が望ましい。この環境を構築するためには、 シナリオトレーニングに関して定量評価できる手法を 確立し、従来の基本操作手技の定量評価と、新たに導 入したシナリオトレーニングの定量評価の関係を明ら かにする必要がある。

本研究では、臨床に扔ける体外循環操作に求められ る総合的な能力の評価を養成校教育で効率よく実施す るため、トレンドグラフを用いた基本操作手技習熟度 の定量評価と、チェックシートを用いたシナリオ達成 度評価の関係性を検討した。

\section{II. 方 法}

本研究では、基本操作手技習熟度を血圧維持習熟度 とした。血圧維持を課題とするトレーニング（以後、血 圧維持トレーニング）の習熟度評価と、チェックシー 卜手法を導入したシナリオトレーニング (以後、チェ ックシートトレーニング）の達成度評価を行った。各 トレーニングの評価内容は、実施できる技術の有無を 評価するものとした。血圧維持習熟度とシナリオ達成 度の定量評価の関係性を客観的に検討するため、血圧 維持トレーニングとチェックシートトレーニングの実 施する順序を変更して 2 群に分類した。血圧維持卜レ 
表 1 シナリオの流れとチェックシートの項目内容

\begin{tabular}{|c|c|}
\hline シナリオ & 項目内容 \\
\hline \multirow{5}{*}{ カニュレーション } & 1 ACT の確認 \\
\hline & 2 返答する \\
\hline & 3 吸引ポンプ Start \\
\hline & 4 送血管カニュレーション $\rightarrow$ 拍動確認 \\
\hline & 5 脱血管カニュレーション ～～返答する \\
\hline \multirow{7}{*}{ 体外循環開始 } & 6 酸素吹送 $\left(\mathrm{O}_{2}\right.$ Flow・ブレンダーのコントロール $)$ する \\
\hline & 7 タイマーStart \\
\hline & 8 Pump On を報告 \\
\hline & 9 適正灌流量 3.5L/min にする \\
\hline & 10 急激なリザーバーレベル変化を起こさない（ $( \pm 300 \mathrm{~mL})$ \\
\hline & 11 Total Flow を報告 \\
\hline & 12 モニタの確認 \\
\hline \multirow{2}{*}{ （呼吸器停止） } & $13 \mathrm{O}_{2}$ Flow・ブレンダーの確認 \\
\hline & 14 返答する \\
\hline \multirow{3}{*}{ 循環維持 } & 15 返答する \\
\hline & 16 平均血圧 70 ～110mmHg を維持する \\
\hline & 17 リザーバーレベル $\pm 300 \mathrm{~mL}$ を維持する (Total Flow になった時のリザーバーレベルを基準とする) \\
\hline \multirow{6}{*}{ 体外循環離脱開始 } & 18 モニタの確認 \\
\hline & 19 返答する \\
\hline & 20 呼吸器再稼動の確認 \\
\hline & 21 流量を徐々に下げる \\
\hline & 22 Hafe Flow で報告 or 流量の報告 \\
\hline & 23 Pump Off 可能であることを報告 \\
\hline \multirow{5}{*}{ 体外循環終了 } & 24 Pump Off を報告する \\
\hline & 25 タイマーStop \\
\hline & 26 モニタの確認 \\
\hline & 27 酸素吹送停止の確認 \\
\hline & 28 返答する \\
\hline \multirow{2}{*}{ プロタミン投与 } & 29 返答する \\
\hline & 30 吸引ポンプストップ \\
\hline
\end{tabular}

ーニングを先に実施した $\alpha$ 群 (47 人)、チェックシー トトレーニングを先に実施した $\beta$ 群（44人）とした。 統計学的手法として、チェックシートトレーニング時 の血圧維持習熟度とシナリオ達成度の評価の関係性に 関する $\alpha$ 群・ $\beta$ 群の比較は、SPSS Statistics 17 の 検 定を使用し、 $\mathrm{p}$ 值 $<0.05$ を有意差ありとした。

\section{1. 血圧維持習熟度の定量評価手法の詳細}

血圧維持習熟度の定量評価手法として、送血流量の 変化に対して目標血圧を維持する課題の習得度を用い た。本課題の達成度は、目標動脈圧に対する患者血圧 の差とした。

\section{2. シナリオ達成度の定量評価手法の詳細}

一連の流れを実施するシナリオトレーニングの評価 手法として、チェックシートによるシナリオ達成度を 用いた。シナリオ達成度は、各訓練者のチェックシー トの点数と、各項目の達成率とした。

\section{3. チェックシート手法の詳細}

シナリオは On Pump Beating の流れを基本とし、心 停止を含まない体外循環操作の流れとした。シナリオ
の流れとチェックシートの項目内容は、表 1 の通りで あり、1 項目 1 点として 30 点満点とした。

養成校教育では多人数を対象とし、効率よくトレー ニングを行える環境が必要であるため、チェックシー 卜手法を活用した。チェックシートをトレーニング教 材とすることで、指導者の存在に依存することなく、 訓練者相互で評価できる環境を構築し、更に 2 人の学 生が同時にトレーニングできる環境とした（図 2)。ま た、チェックシートを振り返りの資料とすることで、 学生自らシナリオ達成度に関して評価できる環境を構 築した。

\section{4. 対象者および実習内容}

対象者は、デー夕の学術使用とその目的に関して十 分な説明を行い、文書により同意を得た医療技術学科 3 年次の学生 91 名 $(4 \sim 10$ 名/グループ) とした。ま た参加に関する同意の可否が当人の不利益にならない ことを説明し、教育機会の均等性が保証されるように 配慮した。

実習内容は、 1 グループ 2 週間で実施し、 1 週間目 


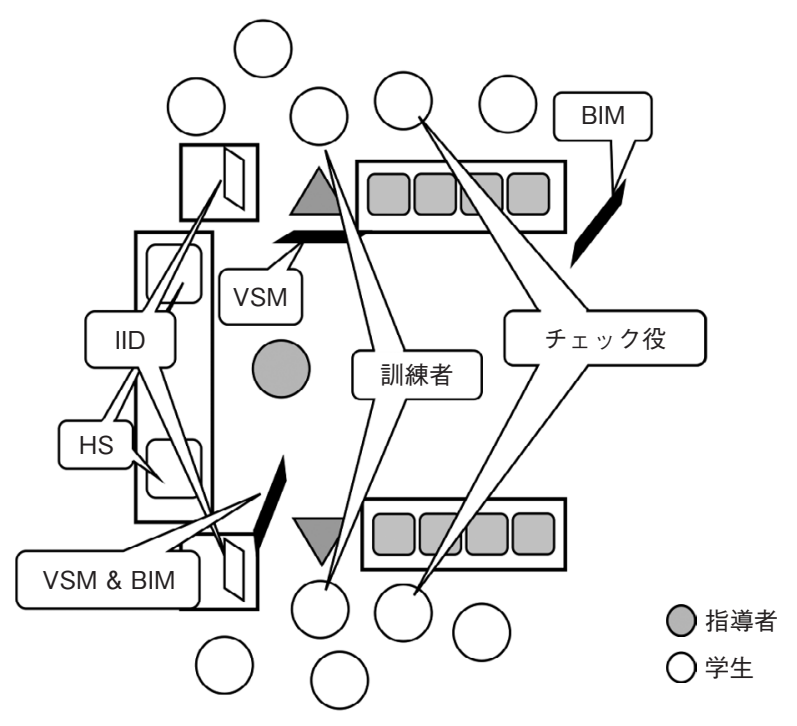

図 2 トレーニング環境

(HS : Hydraulic Section, VSM : Vital Sign Monitor, BIM : Blood gas and Information Monitor, IID : Instructor Interface Display)

にリザーバーレベル維持トレーニング、 2 週間目に血 圧維持トレーニングとチェックシートトレーニング、 それぞれ 180 分で実施した。2 週間目に行ったトレー ニングが本研究での検討内容であり、血圧維持習熟度 とシナリオ達成度の評価を行った。人工心肺装置の設 定は、送血方式をローラーポンプ、脱血方式を鉗子操 作による落差脱血とした。

各トレーニングの詳細は表 2 に示す。各トレーニン グの目的は、リザーバーレベル維持トレーニングが人
工心肺操作を行う上で最も基本的な送血流量・脱血流 量の調節を行う操作技術の習得、血圧維持トレーニン グが患者の血圧を維持する操作技術の習得、チェック シートトレーニングがシナリオの達成・未達成を確認 し、一連の流れを行う操作技術の習得である。実習の 目的は、それぞれのトレーニングを体験して振り返る ことで、それぞれの操作技術の理解を深めることとし ている。

\section{III. 結 果}

血圧維持習熟度の定量評価を最初に実施する $\alpha$ 群と、 シナリオ達成度の評価を最初に実施する $\beta$ 群において、 各評価項目の比較結果を以下に示す。

\section{1. 血圧維持習熟度 (目標動脈圧に対する患者血圧の差)}

チェックシートトレーニング時の目標動脈圧に対す る患者血圧の差について、平均值は $6.16 \pm 2.80 \mathrm{mmHg}$ （目標動脈圧の差 \pm 標準偏差）であった。 $\alpha$ 群の平均 值は $2.15 \pm 3.50 \mathrm{mmHg}$ であり、 $\beta$ 群の平均值は $10.44 \pm$ $2.04 \mathrm{mmHg}$ であった。血圧維持トレーニングは、チェ ックシートトレーニング時の血圧維持習熟度を有意に 向上させることが確認された（p 值 $<0.05 ） 。$

2. シナリオ達成度 (各訓練者のチェックシートの点数) 全学生のチェックシートの平均点は $22.01 \pm 3.92$ 点 (平均点土標準偏差) であった。 $\alpha$ 群の平均点は 22.21 \pm 4.01 点であり、 $\beta$ 群の平均点は $21.80 \pm 3.86$ 点であ った。 $\alpha$ 群・ $\beta$ 群において有意差は認められなかった (p 值 $>0.05)$ 。

表 2 各トレーニングの詳細

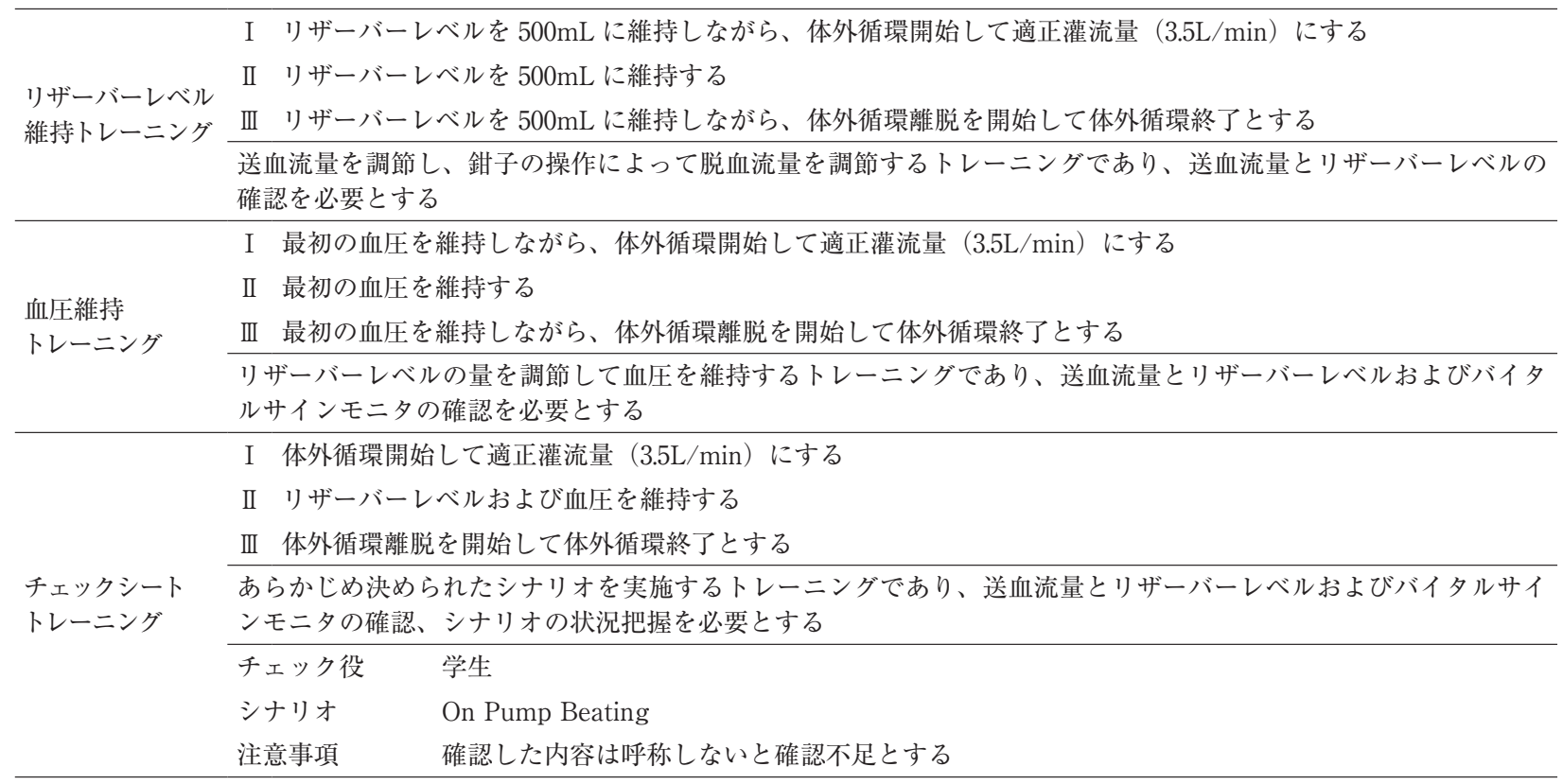

(表中の番号 : 「I， Extra corporeal circulation start $\rightarrow$ Total flow $\rfloor\lceil I$ I , Total flow $\rightarrow$ Weaning start $「$ III, Weaning start $\rightarrow$ Extra corporeal circulation stop $\rfloor$ ) 

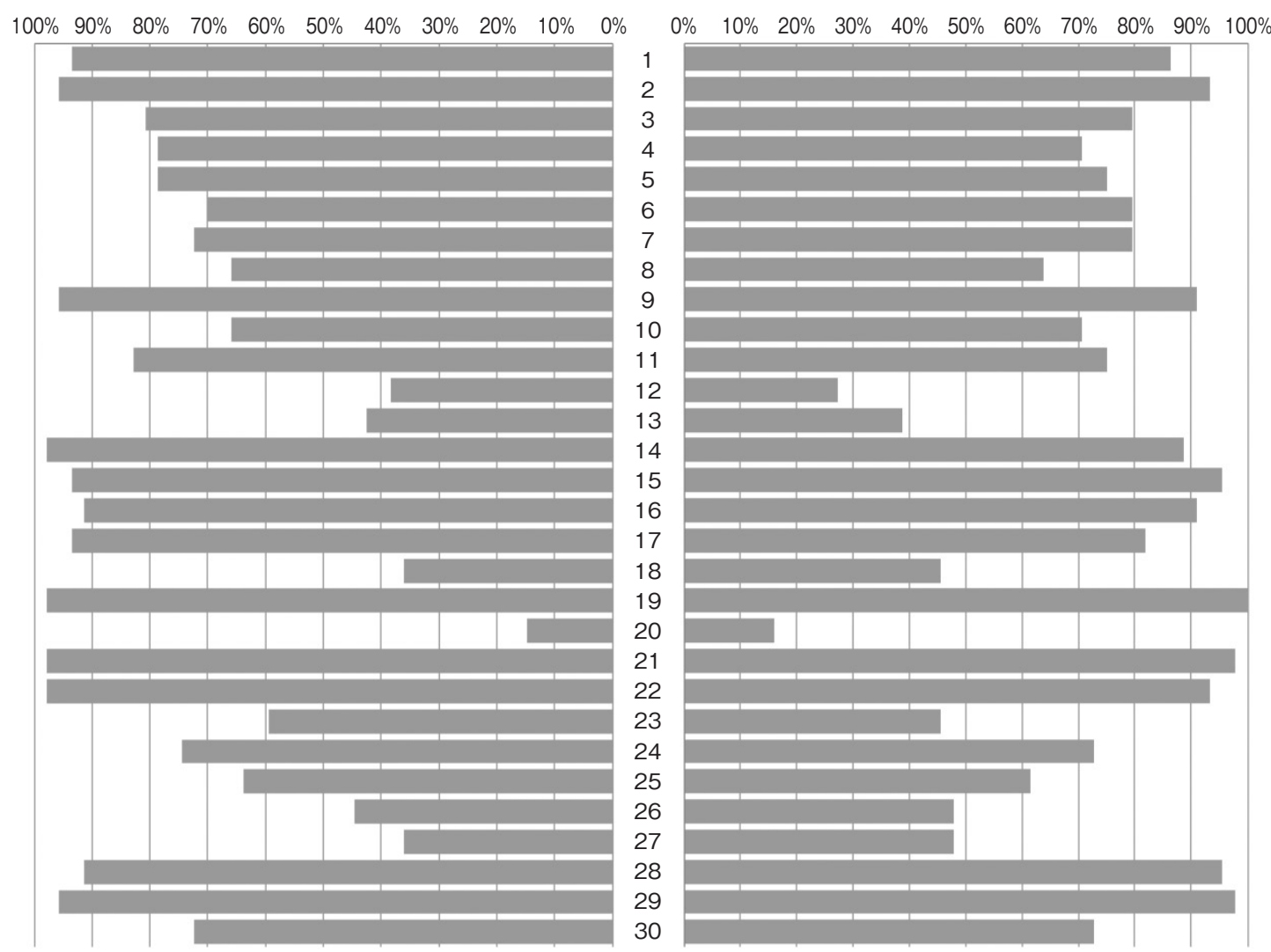

図 3 チェックシート各項目の達成度（ $\alpha$ 群・ $\beta$ 群別）

[横軸：各群に扔ける各項目の達成度（中心 $0 \%$, 両端 $100 \%$ ), 縦軸：表 1 の番号と一致]

\section{3. シナリオ達成度（各項目の達成率）}

チェックシート 30 項目それぞれの達成率について $\alpha$ 群・ $\beta$ 群別の結果は、図3の通りであった。左側に $\alpha$ 群、右側に $\beta$ 群の結果を表示し、横軸に関しては中 心が $0 \%$ 、両端が $100 \%$ とした。縦軸に関しては、チェ ックシートの項目順に並べた（四中の番号：表1の番 号と一致)。 $\alpha$ 群・ $\beta$ 群の各項目に打いて、いずれも有 意差は認められなかった（ $\mathrm{p}$ 值 >0.05）。

\section{IV. 考察}

本研究では、トレンドグラフを用いた血圧維持習熟 度とチェックシートを用いたシナリオ達成度の定量評 価の関係性を検討した。本研究の結果、血圧維持習熟 度とシナリオ達成度の定量評価の関係性、チェックシ 一ト評価の課題について以下の事項が明らかになった。

\section{1. 血圧維持習熟度とシナリオ達成度の定量評価の関 係性}

各評価の関係性を検討する上で、チェックシートの 30 項目中 4 項目が動脈維持習熟度に関する項目であっ たため、血圧の確認 (3 項目) と血圧維持課題 (1 項目) を先に経験した $\alpha$ 群は、シナリオ達成度評価の点数が 高くなると考えていた。しかし $\alpha$ 群は $\beta$ 群と比較して、 チェックシートトレーニング時の血圧維持習熟度を有意
に向上させていたが、シナリオ達成度評価に有意差が 認められなかった。トレーニングを行う際の訓練者は 評価内容を意識するものである。血圧維持習熟度評価 では患者血圧を維持することに意識が集中し、シナリ オ達成度評価ではシナリオを達成することに意識が集 中していたと推察できる。つまり、チェックシートの 項目内容に血圧維持習熟度に関倸する項目が含まれて いても、シナリオ達成度評価時には血圧維持習熟度の 影響がないため、有意差が認められなかったと考える。 シナリオ達成度評価に有意差が認められなかった結 果より、各評価の関倸性を検討する上で考えていた内 容に誤りが存在した。シナリオ達成度評価の点数に $\alpha$ 群・ $\beta$ 群で差がなく、チェックシートの血圧維持に関 連する項目は血圧維持習熟度を反映していなかった。 つまり、各評価を単独で実施しても、血圧維持習熟度 とシナリオ達成度の両方を評価できない。また、臨床 における体外循環操作は、様々な能力を並行して実施 することが要求される。臨床で要求される能力を教育 するためには、どちらの評価も欠かせないため、それ ぞれの評価を並行して実施できる環境構築が求められ る。つまり、各評価を統合したトレーニング様式の検 討が必要となる。

また、授業設計を行う上でトレーニングの順序が各 
評価に影響を与えないことは、トレーニングの順序に こだわる必要がない点で自由度を広げられる可能性が ある。特に多人数を対象として効率性が求められる場 合は、決められた時間内でより多くのトレーニング回 数を訓練者に提供でき、反復練習の効果によって各能 力を向上・上達させることが期待できる。

\section{2. チェックシート評価の課題}

本研究を実施する上で、養成校教育では多人数を対 象とし、効率よくトレーニングを行える環境が必要で あったため、授業設計を行う必要があった。そのため、 チェックシート手法を導入して、指導者の存在に依存 することなく、訓練者相互で評価し、学生自らシナリ オ達成度に関して評価できる環境を構築した。

チェックシート（チェックリスト）手法を目的に応 じて活用する報告の例として、近江ら ${ }^{9)}$ は、世界保健 機関（WHO）により 2008 年に公表され、手術関連の 合併症や死亡を減少させる目的で作成された「手術安 全チェッリスト」の導入を推奨している。また、松島 ら 10)は、授業を行った後に実施したチェックリストの 結果と 3 カ月後に行ったチェックリストの結果を復習 したかどうかで比較し、復習によってスキル習熟度の 低下を防げると述べている。しかし、チェックシート （チェックリスト）で行える評価の内容に関する報告は 確認できないのが現状である。

本研究でチェックシート手法を導入した経験より、 チェックシート評価の内容はシナリオ達成度の評価で あり、シナリオを達成する過程が一連の流れを理解し たことによるものか、暗記したことによるものか判断 できなかった。臨床においては一連の流れを理解した 上で達成することが求められるが、本研究は養成校で 学生を対象とするため、一連の流れを体験して振り返 ることによって、体外循環操作の流れを理解すること が求められる。つまり、多人数教育を前提とする養成 校教育においてチェックシートの活用方法には限界が 存在し、複雑な症例のシナリオやトラブルに対する対 処方法を含むトレーニングは難しい。鈴木 ${ }^{11)}$ は、授 業設計について、教育に関する様々なモデルや原理を 紹介しているが、その中で授業の目標・評価・方法が 三位一体であり適合性がとれている必要があると説い ている。つまり、チェックシート手法の導入を検討す る場合は、目的を明確にし、その目的に応じた方法で 導入することを検討すべきである。

\section{3. 今後の展望}

チェックシートの各項目の達成率に関する結果 (図 3) では、ばらつきが存在した。チェックシートの項目を 「認知・判断・実行・応答・情報共有」の 5 種類に分類 して、各分類の達成率に関して解析を行うことで、ば らつきの理由を明らかにできると考えていた。この解
析を行った結果、「認知」に関する分類の達成率だけ が他の分類と比べて低く、訓練者の特徵（得意・不得 意な分類）を確認できた。この訓練者の特徴を確認で きることは、トレーニングの目的を明確にできるため、 効率的かつ効果的な授業設計を考える上で重要である。 しかし、各項目の達成率にばらつきがある理由を明ら かにできていない。今後この理由を明らかにすること で、訓練者の不得意な分類に対する改善策を導き出せ ると考える。

また、臨床における教育では、総合的な能力として 複雑な内容を評価しているため、本研究で実施した基 本操作手技とシナリオ達成度の定量評価だけでは不十 分である。将来的には、臨床で求められる総合的な能 力を構成している各能力の内容と評価方法を明らかに して、各能力の評価を並行して行える環境構築が望ま れる。この各能力の内容と評価方法を明らかにするこ とで、養成校における教育と臨床における教育の間に ある差を埋められることが期待できる。

\section{V. 結 論}

本研究では基本操作手技習熟度とシナリオ達成度の 各評価の関係性を検討する上で、以下の内容が明らか になった。

1）基本操作手技とシナリオ達成度の定量評価を統合し たトレーニング様式を検討する必要がある。

2）トレーニングの順序が各評価に影響を与えないこと は、授業設計を行う上で自由度を広げられる可能性 がある。

3）目的に応じた方法でチェックシート手法導入を検討 すべきである。

\section{【謝辞】}

デー夕収集や本研究にご協力いただいた広島国際大学 保健医療 学部 医療技術学科 2014 年度 3 年次の学生の皆様に深く感謝いた します。

本稿のすべての著者には規定された COI はない。

\section{参考文献}

1）冨澤康子, 四津良平, 神谷勝弘, ほか：体外循環のトラブ ルシミュレーション：ウエットラボの経験. 人工臓器, 35 (1) ; 233-236, 2006.

2）渥美杜季子, 関口 敦, 見目恭一：ウエットラボ体験から 学んだトラブルシミュレーションの重要性. 人工臟器, 35 (1) ; 237-239, 2006.

3）小久保領, 又吉盛博, 星野敏久, ほか：シミュレーション 教育の重要性一ウエットラボを体験して一. 人工臓器, 35 (1) ; 240-243, 2006.

4）一般社団法人日本体外循環技術医学会 安全対策委員会 教 育委員会 :「人工心肺に関する安全装置に関するアンケート 2014」についての結果報告. 体外循環技術，42（2）；172-183， 
2015.

5）二宮伸治，徳嶺朝子，黑崎達也，ほか：体外循環シミュレー ションシステム ECCSIM および ECCSIM-Lite. CIRCULATION Up-to-Date, 4 (1)；22-32, 2009.

6) Ninomiya S, Tokaji M, Kurosaki T, et al. : The virtual patient simulator for the perfusion education in Japan. Indian Journal of Extral-Corporeal Technology. 21 (1) ; 12-17, 2011.

7) Tokumine A, Ninomiya S, Tomizawa Y, et al. : Evaluation of basic perfusion techniques, ECCSIM-Lite simulator. J Extra Corpor Technol. 42 (2) ; 139-144, 2010.

8) Tokaji M, Ninomiya S, Sueda T, et al. : An educational training simulator for advanced perfusion techniques using a high-fidelity virtual patient model. Artif Organs, 36 (12); 1026-1035, 2012

9）近江明文, 寺井由香子, 野口 将：WHO「手術安全チェッ クリスト」の実践的活用法一中規模総合病院と大学病院に 導入した経験から一. LiSA，21（4）；344-350， 2014.

10）松島久雄, 菊地 研, 井上晃男, ほか: 医学生への e-learning を用いた蘇生教育. 日救急医会誌，24（6）；374-376，2013.

11）鈴木克明：インストラクショナルデザインとしての授業設 計. 看護教育, 54 (4)；259-264，2013. 